УДК 339.138

JEL M31

HRINCHENKO Y.L.

PhD. Econ. Sciences, associate professor

Chair of marketing and business administration

Odesa National Mechnikov University,

Frantsuzkyi boulevard, 24/26, Odesa, Ukraine, 65044

E-mail: hrinchenko@yahoo.com

ORCID: 0000-0002-9439-5933

ROBUL I.V.,

PhD. Phys. Sciences, associate professor

Chair of marketing and business administration

Odesa National Mechnikov University,

Frantsuzkyi boulevard, 24/26, Odesa, Ukraine, 65044

E-mail:yrobul@gmail.com

ORCID: 0000-0002-7299-9648

ZALUBINSKA L.M.,

PhD. Phys. Sciences, associate professor

Chair of marketing and business administration

Odesa National Mechnikov University,

Frantsuzkyi boulevard, 24/26, Odesa, Ukraine, 65044

E-mail:lnz@ukr.net

ORCID: 0000-0002-1866-0125

\title{
DEVELOPMENT OF PRICE STRATEGIES TO SUPPORT BRAND POSITIONING: STRATEGIC ISSUES FOR MARKETING POLICIES
}

Topicality. Marketing policies become more sophisticated and more focused nowadays. On many consumer markets there is a trend for differentiating and branding products as a response to defragmentation of the market. Brand is no more just a promotion tool; it shapes the company-customer relations for a long period. Brand is a concept completely based on understanding customer needs and evaluating related values. Meanwhile pricing policy remains a conservative part of marketing, which relies mostly on internal factors. Brand requires a careful positioning and price has to follow. Transforming the pricing into a powerful strategic instrument for gaining a desired marketing segment implies price positioning. The problem of it relates to the dilemma of meeting customer expectations concerning their willingness to pay and financial objectives based on profitability.

Aim and tasks. The purpose of the article is to identify the conceptual framework for development a pricing strategy, which follows brand positioning and ensure targeted profit requirements. To develop an appropriate pricing policy a comprehensive process of positioning shall be structured a step-by-step process. Positioning may relay on different factors ranging from quality and consumer value to competitors' prices and benefits. A coordinated policy decisions shall follow. The next task is to ensure financial effectiveness of price policy. That requires a profound analysis of both external and internal factors. Strategic vision will reflect the positioning target. The several options of pricing strategies appear and the task of the company to choose the most appropriate one.

Research results. Pricing itself shall not be rigid, but its main goal - to support the brand development strategy. There are three general options for such strategies. The first one focuses on increasing sales profits among loyal customers. Therefore, the brand is becoming more focused, its promotion is more aggressive, and the positioning is more consolidated. Usually, the price increases gradually, first on new product modifications, special series, in conjunction with additional services, and so on. But the price increases as long as consumer loyalty is not compromised. The second strategy is aimed at increasing the segment of loyal consumers by "catching" consumers, loyal to other brands or disloyal to any brand in general. One of the options for such a delusion involves aggressive pricing. In most cases, a product with extremely competitive "price-quality" and powerful marketing support is being created, aimed at forming a new group of loyal consumers. As a result, the price will not change in the long run while sales are increasing. The key to succeeding in this policy is to prevent loyal customers from being "lured" to new consumers. The third version of the strategy of brand 
development implies its expansion into new segments of the market. The focus of the brand becomes more vague, it is more focused on the properties of the product, but not on consumer preferences. Price becomes less emotional, but more rational factor of consumer choice. Pricing becomes similar to that of the non-branded market.

Conclusions. Thus, to achieve sustainable financial objectives shall consider mostly irrational pricing factors, among which the willingness or desire of consumers to pay a price for the product is the most prominent. Branded markets are determined by the predominance of irrational aspects of pricing. Therefore, the pricing strategy is aimed at the intensive use of communication tools. However, rational factors such as the volume of the target market segment, consumer value and competitive price also play an important role in shaping the financial success of pricing on markets of branded products.

Key words: positioning, pricing, brand, pricing strategy, marketing strategy.

\title{
УДК 339.138
}

JEL M31

ГРІНЧЕНКО Ю.Л.

к-т екон. наук, доцент.

кафедра маркетингу та бізнес-адміністрування.

Одеський національний університет ім. I.I. Мечникова Франиузький бульвар, 24/26, м. Одеса, Украӥна, 65044

E-mail:hrinchenko@yahoo.com

ORCID: 0000-0002-9439-5933

\section{РОБУЛ Ю.В.}

$\kappa-m$ ф-м. наук, доцент.

кафедра маркетингу та бізнес-адміністрування.

Одеський національний університет ім. I.I. Мечникова

Французький бульвар, 24/26, м. Одеса, Україна, 65044

E-mail: yrobul@gmail.com

ORCID: 0000-0002-7299-9648

\section{ЗАЛЮБІНСЬКА Л.М.}

$\kappa-m$ ф-м. наук, доичент.

кафедра маркетингу та бізнес-адміністрування.

Одеський національний університет ім. I.I. Мечникова

Франиузький бульвар, 24/26, м. Одеса, Украӥна, 65044

E-mail:Inz@ukr.net

ORCID: 0000-0002-1866-0125

\section{РОЗРОБКА ЦІНОВИХ СТРАТЕГІЙ, ЩО ПІДТРИМУЮТЬ ПОЗИЦІЮВАННЯ БРЕНДУ: СТРАТЕГІЧНІ ЧИННИКИ МАРКЕТИНГОВОЇ ПОЛІТИКИ}

\begin{abstract}
Актуальність. Маркетингова політика на сьогоднішній день стає більш комплексною $i$ більш орієнтованою. На багатьох споживчих ринках існує тенденція до диференціації та брендінгу продукиії як відповідь на дефрагментацію ринку. Бренд - че не просто інструмент просування; він на довгий час формує відносини між компанією та клієнтами. Бренд - це концепція, яка повністю трунтується на розумінні потреб клієнтів та оцінці відповідних ичінностей. Тим часом цінова політика залишається консервативною частиною маркетингу, яка в основному спирається на внутрішні чинники. Бренд вимагає ретельного позиціонування та дотримання ціни. Перетворення ціноутворення на потужний стратегічний інструмент для отримання бажаного сегмента маркетингу передбачає цінове позиціонування. Проблема пов'язана з дилемою задоволення очікувань клієнтів щзодо їх готовності платити певну изіну та фінансових ичілей на основі прибутковості.

Мета та завдання. Метою статті $\epsilon$ визначення концептуальної основи розробки стратегії ціноутворення, яка відповідає позиціонуванню бренду та забезпечує цільові вимоги до прибутку. Для розробки відповідної політики ціноутворення структурований комплексний процес позиціонування має бути розроблений та впроваджений по кроках. Позиціонування може стосуватися різних факторів, починаючи від якості та споживчої цінності, до цін і переваг конкурентів. Наступним завданням є забезпечення фінансової ефективності цінової політики. Це вимагає глибокого аналізу як зовнішніх, так і внутрішніх факторів фірми. Стратегічне
\end{abstract}


бачення відображатиме иүіль позиціонування. 3'являються кілька варіантів иінової стратегії, а завдання компанії вибрати найбільш відповідний.

Результати досліджень. Сама цінова політика не повинна бути жорсткою, але ї̈ головна мета підтримати стратегію розвитку бренду. Існують три загальні варіанти таких стратегій. Перший з них зосереджується на збільшенні прибутку від продажів до лояльних клієнтів. Тому бренд стає більш цілеспрямованим, його просування більш агресивним, а позиціонування більш консолідованим. Як правило, ціна поступово зростає, спочатку на модифікачіях нового продукту, спеціальних серіях, у поєднанні з додатковими послугами і так далі. Але ціна зростає до тих пір, поки лояльність споживачів зберігається. Друга стратегія спрямована на збільшення сегмента лояльних споживачів шляхом "захоплення" споживачів, лояльних до інших брендів або нелояльних до будь-якого бренду взагалі. Одним з варіантів такої політики є агресивне ціноутворення. У більшості випадків створюється продукт з надзвичайно конкурентоспроможним співвідношенням "цінаякістю" і потужною маркетинговою підтримкою, спрямованої на формування нової групи лояльних спожсвачів. В результаті ціна не зміниться в довгостроковій перспективі, у той час як продажі зростають. Ключем до успіху в цій політиці є запобігання "заманюванню" лояльних клієнтів на противагу до нових споживачів. Третя версія стратегії розвитку бренду передбачає ї̈ розширення на нові сегменти ринку. Акцент бренда стає більи розпливчастим, він більше орієнтований на властивості продукту, а не на споживчі уподобання. Ціна стає менш емоційною, але більш раціональним фактором вибору споживача. Ціноутворення стає подібним до цін на небрендованому ринку.

Висновки. Таким чином, для досягнення стійких фінансових цілей необхідно враховувати в основному ірраціональні фактори ціноутворення, серед яких найбільш важливим є бажання споживачів платити за продукт певну ціну. Брендовані ринки визначаються переважанням ірраціональних аспектів ціноутворення. Тому цінова стратегія спрямована на інтенсивне використання засобів комунікації. Раціональні фактори, такі як обсяг сегмента цільового ринку, споживча вартість та конкурентоспроможна ціна, також відіграють важливу роль у формуванні фінансового успіху ціноутворення на ринках брендованої продукції.

Ключові слова: позиціонування, ціноутворення, бренд, иінова стратегія, маркетингова стратегія.

Problem statement and its connection with important scientific and practical tasks. Marketing policy as a management tool develops into a complex issue involving many issues within a firm of both external and internal origins. Still marketing is about knowing the customers and focusing on their needs. The key factor for overall success of marketing policy is right positioning on the market. Positioning along with technology and production issues defines the product features, it sets the frontiers for selling volumes and it clarifies perspectives for future profits. Knowing which product to offer in which market (product-market combination) is of crucial importance for keeping a business profitable. Positioning your product or service is even more important, as it delivers long-lasting effects. Positioning refers to the image you want to print in your customers' heads or, in other words, the impression you want to leave on your target group of customers. In a world where we are constantly inundated with advertising, your product or service must stand out from the rest of the pack. A "positioning statement" is therefore often based on competitive advantages. What do you do better or what do you offer different from others? What features or properties make your product or service so unique? This task is far from obvious exercise, as most products / services are just not unique or superior. So the positioning has two-way effect, it shows a company's view of its target customers but also it shapes the customer expectations toward its product/service offer. Nevertheless, by giving you a clear positioning, you will be able to communicate the added value of your product / service in a consistent and attractive way to the address of your target audience. In short, this is the essence of a good marketing strategy.

Analysis of recent publications on the problem. As Simon, Bilstein and Luby stated in their research the pricing is one of the most flexible policy of the marketing mix, which affects directly over the profitability and cost effectiveness of a company. Despite the importance a price has on the performance of businesses, it seems that pricing has not received the proper attention by many academics and marketing professionals, as Avlonitis \& Indounas observed. In the mainstream of policy research in marketing, policy-makers focus on the development of new products, distribution channels and communication strategies, and according to Lancioni this could lead to precipitated pricing decisions without properly evaluating market and cost factors. As a research of Nagel and Holden revealed, only few managers strategically thought about pricing. Altough they while constantly administrating their prices in order to create favorable conditions for profit earning. Considering this, Liozu and Hinterhuber highlighted the need for more research regarding the pricing preferences and practices because, according to the authors, less than $2 \%$ of all published articles in marketing journals are focused on pricing.

Strategic pricing requires a stronger relationship between marketing and the other functions of a company. In order to ameliorate companies' economic and financial performance, the pricing policies should 
encompass internal capacities and needs and wishes of their customers, in addition to market conditions such as, economic conditions and degree of competition. Some researches as one by Besanko, Dranove, Shanley\&Schaefer and one by De Toni\&Mazzon studied relations of pricing and a better performance of the company. In a study about pricing and expenditure strategies developed by Milan, De Toni, Larentis, and Gava, the conclusion stated that the factor that mostly influenced an organization's performance was related to the achievement of objectives by the development of new products. In other words, businesses that achieved their sales, market participation and profit margins objectives exhibited a better organizational performance.

Liozu, Boland, Hinterhuber, and Perelli conducted a research mapping the pricing processes of companies which based their prices on competitors. The research resulted in the findings that managers used their knowledge and experiences to define prices, as well as models of costs, contribution margin goals, and wellstructured profit goals. In addition, these companies were strongly considering the prices of their main competitors. Adding a price reward was mostly a decision based on the manager's intuition, which is not a scientific method to define prices. Similarly, a study of 84 companies performed by Milan et al. showed that in these companies there was a greater focus on price setting based on costs. Thus, this strategy encourages companies to use better expenditure techniques. Liozu conducted a study by interviewing forty-four of their managers of fifteen small and medium-size American companies. In the study, he addressed the three main pricing strategies: customer value-based pricing (in four companies), cost-based pricing (in six companies) and competition-based pricing (in five companies). The study identified that the majority of the companies basing their prices on costs developed advanced cost models, all of which used contribution and profit margin goals in order to set their prices. According to Hinterhuber, the impact of price levels on profitability is high, which means that even the impact of small increases of price on profits and corporate profitability by far exceeds the impact of other leverages in managing best results. In his study, it was possible to detected that a 5\% increase in average sales prices may increase the earnings before interest and taxes (EBIT) by 22\%, on average, compared to a $12 \%$ increase on the sales volume and a $10 \%$ cost reduction of sold goods, respectively. In other words, of all the elements available to managers, the price is what has the larger impact on corporate results, reflecting on representative gains, as Kohlia\&Surib found on their study.

Allocation of previously unsolved parts of the general problem. Most of the attention concerning positioning under marketing policy relates to the fit of product's features to customers' needs. Not so many studies address the price dimension of positioning. For most companies pricing is mostly about tactics not about strategy, parts of which positioning is. Price positioning requires a specific vision of market segments. Options of targeted price policies based on positioning shall be elaborated for further consideration.

Formulation of research objectives (problem statement). Internal factors, such as costs and production schedules, have great impacts on pricing. Consumer value remains vague and hard to measure. To launch a proactive marketing policy a company needs to develop pricing policies, which support its market goals but simultaneously meet financial objectives. Price positioning along with brand development is one of possible solutions.

Outline of the main results and their justification. Marketing practice exploits a five-step positioning process. This process is regarded as a value-communicating one. The value of your product or service is expressed by the benefits it offers to its recipient. These can come in different forms:

- Functional: solves problems, offers benefits such as speed, etc.

- Psychology: feeling of security or belonging, better self-image, etc.

- Experimental: better "touch", better service delivery, better interaction, etc.

In its classical presentation the process of positioning consists of following steps:

Step 1. List the benefits of your product.

Step 2. Gather information about the perception of your customers.

Step 3. Identify competing products and analyze how they position themselves: the fastest, the best, the cheapest, and so on.

Step 4. Compare your positioning to that of your competitors (matrix) and try to establish distinctive features or look for points of differentiation.

Step 5. Determine your own position, based on the values and distinction made above.

This process tends to repeat continuously as new product attributes appeal to customers or new market space appears. Companies need to search for new product features to distinguish themselves from competitors in a more clear way. Any shifts of marketing strategy will require some changes or total makeover positioning.

There are a few points to describe a good positioning statement: 
- the product / service you offer;

- the target group you are addressing

- the problem inherent in your target group;

- how you want to solve it with your product / service

- how you stand out from your competitors

- the main features or properties of your product / service.

In other words a good positioning statement declares: "We provide ... (your service or product) to .... (target group) who regularly faces ... (problem). Unlike ... (cite competing products or services), our product / service can / is ...... (name the main features of your product or service that make it stand out from the competition)". In that perspective, positioning serves for differentiating your company from your competitors and it heavily relates on product attributes. It is easy to notice that pricing does not appear in that classical view of positioning as a marketing tool. As branding practice spread across industries its pricing dimension gained importance. Contrary to product specifications, pricing boundaries between customer segments are more vague and hard to detect. Despite the fact that the price of a product is a major factor of a purchase decision, marketing strategies adopted approach of a value-containing product. Every attribute of a product needs to contribute a customer value. The price balances the customer value, but it is not though a customer segment factor. The price just follows the product attributes. The evidence of marketing strategy implementation shows that mistakes about pricing occur more often and cost much more than the product ones.

There are several options for positioning within a marketing strategy.

Option 1. Positioning based on quality.

The quality of a product is one of the core component of a company brand. Even more important that positioning based on quality can be easily combined with other positioning strategies. Since every company is targeting to emphasize its commitment to quality, the product attributes is right factor to distinguish the company from competitors. The best way is to narrow consumers' focus to one area of expertise, thereby branding the company as a high-quality and trusted specialist. Pricing policy sticks to quality perception of consumers. The price indicates the quality of the product to the customer, depends on product performance, and attributes. Positioning supports the existent price boundaries among segments and pricing is more rigid.

Option 2. Positioning based on value.

There are two approaches to value or price positioning, both of which are heavily dependent on quality. One approach is to use a high-end positioning, which supports the belief that high quality is a reasonable excuse for high price. Eventually the high-end price becomes a mark for high-end quality. A company can also cement its brand as the provider of high quality, value-priced products or services. A good example of this strategy is Southwest Airlines. In a tough economy, its policy of offering affordable flights as well as promising free checked luggage has allowed it to flourish while other airlines struggle. Pricing loses direct connection to quality. It perfectly adjusts to current market conditions and consumers' willingness to pay. So positioning only communicates to a certain segment, but price decisions are flexible.

Option 3. Positioning based on benefits.

This strategy implies communicating the unique benefits of a product or service to the target segment of the market. With this strategy, the goal is to highlight the company's most powerful attributes - the ones that no competitor can claim and that are valuable to the consumer. Highly priced home appliance of German brands like Bosch or Miele built their strength on the benefits of repair. These appliances were considered as ones that almost never require any repair for long time. Positioning mostly rely not on price levels, but goes deep into consideration of economic benefits of the product. Pricing follows such benefits, so is very exposed to external factors.

Option 4. Positioning based on problem and solution correspondence.

Positioning a brand as the solution to a consumer's problem is a powerful strategy. The central point is to show that your company has the ability to relieve customers of whatever problem they may be facing, both quickly and efficiently. For example, prepackaged frozen dishes solve the consumer's problem of timeconsuming food preparation. Price positioning is a crucial factor for the marketing strategy. Solution value can be very individualistic and subtle to measure. The price anchors perceptions of economic value of proposed solutions.

Option 5. Positioning based on competitor.

Competitiveness is the key factor for survival for every business. A company needs to demonstrate its superiority over another competitor or competitors, which offer the same type of product or service. Banking 
institutions often employ this strategy to establish a powerful brand by comparing their rates or service to those of other companies. The message is that consumers should obtain their banking services of the same quality but for lesser fee. Price positioning directly targets competitors' price levels.

Option 6. Positioning based on celebrity image.

Hiring celebrities as spokespeople or to endorse a company's product or service is a popular way to position a brand. The celebrities can quickly increase brand awareness among customers and build strong associations to some features linked to prosperity. This positioning may be expensive. The consumer tends to trust celebrities implicitly they look familiar. This familiarity inspires buyers to follow the celebrity's lead or to emulate him, making this strategy ideal for selling luxury goods or specific goods as sports equipment. Price positioning usually targets uncovered segments and aims to fix brand within its limits. High-end option is also popular.

In a context of non-growing or lowering consumer demand and simultaneously increasing the number of alternative suppliers in the vast majority of industries, one of the most important tasks of modern marketing is to build sustainable competitive advantages. Marketing has become a strategic business management tool. However, the strong competitive advantage is not the sole reason for the successful operation of the business. Large volumes of sales in absolute terms should be accompanied by a high level of profitability; otherwise, the long-term prospects of any business will quickly vanish. Currently, most managers focus on the financial result of marketing activity in general, or the effectiveness of individual marketing activities. The result of most studies on similar topics is the conclusion about the need to create a powerful brand as a guarantee of sustainable profitability if you talk about the consumer market. The brand is not the only option for fixing profitability rates for a certain period, but by far one of the popular as it targets several problems with customer expectations, supply-chain pressure and competition dynamics.

When it comes to the brand, managers often understand the latter as a certain set of product attributes that determine the level of perception of the quality of the product by the consumer. Accordingly, a powerful brand is, first of all, compliance with consumer requirements of a large portion of consumers of a particular market. Traditionally, brand positioning is one of the tasks of branding. Eventually branding, and positioning, which it incorporates, become a key strategic issue of competition. The chosen positioning dictates directions of development of product, distribution and, most interestingly, pricing policy. That provokes some conficts as the price serves as a marker for positioning but simultaneously shall follow product attributes.

Of course, the price is a significant factor of the consumer choice. However, the task of a brand is often to weaken pricing impact. So, in marketing, the question arise whether the brand and the price are antagonists or additive parts of a marketing complex? After all, the price is not a simple promotion action, but a certain barrier to the consumer's purchase of the product.

Modern marketing has advanced far behind in understanding the nature of consumer value and in defining the factors that shape it. However, the tools available to the vast majority of companies do not measure it neatly. Many pricing strategies turn to be financially inaccessible and suitable only for certain industries. Consequently, consumer value remains an ephemeral substance in order to serve as a benchmark for price fixing. Thus, in practice, most price decisions are still cost-based, although this contradicts the concept of marketing.

Robert Dolan and Hermann Simon, in their famous book "Power Pricing," argued that $84 \%$ of managers of large American corporations had all the information they needed about their expenses, and $81 \%$ were aware of fixed costs. Level of awareness about price levels of competitors reaches $75 \%$. At that time, managers are less optimistic about their level of consumer awareness. The best of all managers are the level of consumer value of the product $-61 \%$ estimated the level of available information as sufficient for decision-making. At the same time, only $34 \%$ of managers believe that they have the necessary information about the reaction of consumers to price changes. And only $21 \%$ have a clear idea of the level of willingness (willingness) of consumers to pay the set price. Since 1995, when the study was conducted, the situation has changed for the better. This is especially noticeable in the case of a reaction to price changes. Today, companies are much more aware of fluctuations in demand, depending on price changes. Sensitivity analysis is a powerful marketing tool that allows to predict the value of key market indicators, such as sales, depending on price convergences. Still it relates mostly on a retrospective analysis; big data technologies quickly change the situation.

The desire of consumers to pay the set price is a less rational phenomenon, so it is harder to take into account when making price decisions. Behavioral and other contextual factors determine the consumer's desire to pay the certain price, but such factors are more difficult to analyze. Five main factors can be named, which help to determine more accurately the price level as a factor of the willingness of consumers to pay the proposed 
price. First, the desire to pay a price directly depends on price incentives. But that is true when to consider relative incentives, that is, the ratio of discount to price, but not absolute. Discounts of UAH 20 more weighty for a product at a price of UAH 100 than 1000 hryvna. Secondly, the consumer always tries to build his relation to the price on the basis of certain reference prices. Therefore, the company controlling the reference prices controls the desire of consumers to pay a certain price for the product. How much does a plane cost from Kiev to Odessa, if the flight to Dnipro is worth, for example, 4500 hryvna? When you look for answers to this question, you take into account the reference prices. Thirdly, consumers' understanding of price components can determine their willingness to pay a price that they would otherwise consider unreasonable. Fitness centers with new equipment shall be more expensive or not? Fourthly, the consumer may consider a justified or unjustified increase in prices depending on the product category and contextual factors. Price increase of hotels in the season is perceived by consumers more readily than the cost of beach towels. Fifthly, the consumer not only assesses the economic viability of the purchase, but also the "fairness" of the price.

In the vast majority of cases, errors in pricing negatively affect either the volume of sales, or the volume of profit, or two these figures at a time. So the relevant question is to determine the typical reasons why companies make so many mistakes.

One of the reasons for the problems of pricing is the blurring of responsibility among several functional structures of the organization - finance, sales, marketing, production, etc. In each company, the final decision on the price is set on its own algorithm. It is not always obvious that the opinion of the functional department would be under consideration in each particular case. As a result, pricing decisions may not consider all relevant market conditions. In the long run, that means the price evolves into a correction mechanism for market position post factum. If the expected results do not correspond to the plan correction to pricing are a usual measure to undertake to boost sales. As a result, profitability is significantly reduced, even if the sales situation has been improved.

There is also a reverse situation. The price is set at the level of the estimated consumer. As noted above, a precise estimate of the level of consumer value in financial terms is based on uncertain methods and many assumptions. Multiple factors affect consumer value for a single customer, let alone the segment of the market. Therefore, it is not surprising that in the real world the price often does not coincide with the corresponding value for consumers, and that situation instantly affects sales.

However, we can state the rapid progress of marketing practices in this field. We can observe increasing number of cases, where companies accurately measure consumer value and set the appropriate price. Firstly, this is facilitated by a deeper understanding of the factors affecting the level of consumer value, and secondly, the proper financial assessment of consumer value is the result of tracking the dynamics of a specific market, including price fluctuations.

A common practice is to focus on price levels that have already emerged on the market. Modern consumer markets have a branched structure, dynamic, but definite segments, a certain pattern of competitor prices. In this case, the price of the product directly depends on the positioning of the product in relation to the competitors' products. This method has many advantages. The price corresponds to the competitive positioning of the product, it is understandable for consumers and trading partners. However, among the main drawbacks of this approach is a passive marketing strategy of the company. The company is moving in the direction of market changes, quickly makes adjustments to the marketing strategy, adjusts pricing policy. Altough the company only follows market dynamics with inevitable time lag. But financial results in this case are the result of market dynamics.

Many companies have fallen into a market-driven trap. Negative market dynamics reduces company profits, but it can not offer an adequate response, including pricing. In addition, most consumer markets have increasingly become a homogenized products ones over time. It reflects on the average profitability in a negative way.

Effectiveness of pricing both from the point of view of marketing and the position of finance - that is, in the categories of competitiveness and profitability, is an important task of strategic management, including strategic marketing. The price will turn from a passive to an active element of managing the market position of the company. This is especially important in the market of branded products, because in these markets positioning is the foundation on which I am building the entire marketing mix.

Price positioning takes a leading position in the marketing plans of many companies and this trend is intensifying. However, at the sub-strategic level, the price continues to be more a re-active thab a pro-active 
tool. For many companies pricing policy coordination with other policies under the marketing-mix concept still lacks a firm ground. The passive role of pricing will inevitably leads to a detioration of financial results.

The brand is the factor, which simultaneously reduces the influence of the price on consumer choice and increases its impact on the financial result. The task of the brand in terms of impact on gross profits - creating additional consumer value and / or strengthening consumer loyalty. A brand as an additional component of consumer value requires the full compliance of the whole set of attributes of the product with consumer expectations. Therefore, it is necessary to carefully determine the price, which is as an important element of positioning as the physical properties of the product, design, warranty, etc. Most consumers have a clear personal idea of the relationship "price - quality", so changes in one element will definitely affect the perception of others. Business practice shows that it is often more appropriate to create a new brand than to set a new price for the old one.

In the most cases, consumers are more conservative in relation to the price than the product. Consumers are enthusiastic about innovations in the product, but they are very cautious about price experiments. This is equally true for both lowering and rising price levels. Of course, companies consider changing the price of their products, primarily within the framework of repositioning programs for brands. But this is usually done very carefully. Individual product lines, sub-brands are issued - and then a strategic decision on price correction is taken on the basis of consumers' reaction. This is equally true for brands that are positioned in the upper and lower price segments. Price correction is based on clear rules - firstly, the preservation of sales among loyal consumers, and secondly, sales should increase in a larger proportion than the corresponding reduction in prices.

However, the price on the market determines not only the manufacturer or the owner of the brand. Resellers have no less impact on it. So, for consolidation of the price offer and its rigid fixation for the end user, the issue of management of integrated supply chains becomes an important issue.

Consumers may not fully understand when the price of a product is too high or too low compared to competitors. In emerging markets, consumers are also disoriented about "fair" prices with respect to consumer value, so companies, in the context of a successful promotion strategy, can capture price levels that will serve as a benchmark for consumers in the future. An illustration of the phenomenon of gradual formation of consumer value and price perception can serve as a market for organic food. Over the past five or six years, a price surplus has been generated in relation to conventional products, although at first the market demonstrated a large variety of producer approaches to pricing.

In the case of a brand policy development as a tool for increasing consumer loyalty, price strategies are not so unambiguous. In the static case, the price decision is by a great degree trivial. The price should be set in the range where demand elasticity is low. However, for any product there is a certain price level beyond which the switching of loyal customers to competitor products or substitutes significantly intensifies. If a company aims to maximize profits in specific market conditions, for a loyal customer segment, it must set the maximum price that they agree to pay for the benefits of a particular brand. The ability to balance on the thin edge of an optimal price requires accurate calculation of the number of loyal consumers and a precise assessment of the consumer value that the brand generates. Tasks are complex, but quite realistic for execution.

If the sales volume is inferior to the projected volume of the segment of loyal consumers, then one of the possible reasons may be an overpricing that pushes consumers loyal to the brand to buy competing products. In this case, price decisions can be very effective in terms of reaching the target segment. If the price premium for loyal consumers seems to be low, then this is primarily a problem of brand promotion policy rather than pricing policy. It should be noted that this price premium is eventually subject to erosion in most markets. This can only be prevented by investments in brand development. If sales have reached the limit of the segment of loyal consumers, then a further decline in price offers is ineffective. The inflow of new consumers is stopped, and the margin is shrinking. Consequently, a company's mistake in estimating the volume of the target consumer segment can lead to prices which are too low (in most cases). This situation may refer to case when prices are lower than the consumer value. But the worse thing is that such a price level forms corroded price guidelines for consumers. Thus, the company in advance reduces the space for price maneuvers, setting price limits, which determine the desire of customers to pay a certain price for the product. Rarely, the company is setting a price too high and investing a lot in increasing the consumer value of its product, including the brand. However, lowering prices would be a more rational solution, as sales significantly increase to the limits of the real, rather than the planned, consumer segment. In the worst case, the company opens a «price umbrella» - leaves the uncovered segment of the market where the competitors come. 
Pricing itself shall not be rigid, but its main goal - to support the brand development strategy. There are three general options for such strategies. The first one focuses on increasing sales profits among loyal customers. Therefore, the brand is becoming more focused, its promotion is more aggressive, and the positioning is more consolidated. Usually, the price increases gradually, first on new product modifications, special series, in conjunction with additional services, and so on. But the price increases as long as consumer loyalty is not compromised.

The second strategy is aimed at increasing the segment of loyal consumers by "catching" consumers, loyal to other brands or disloyal to any brand in general. One of the options for such a delusion involves aggressive pricing. In most cases, a product with extremely competitive "price-quality" and powerful marketing support is being created, aimed at forming a new group of loyal consumers. As a result, the price will not change in the long run while sales are increasing. The key to succeeding in this policy is to prevent loyal customers from being "lured" to new consumers.

The third version of the strategy of brand development implies its expansion into new segments of the market. The focus of the brand becomes more vague, it is more focused on the properties of the product, but not on consumer preferences. Price becomes less emotional, but more rational factor of consumer choice. Pricing becomes similar to that of the non-branded market.

The combination of marketing objectives of competitiveness and financial goals is quite possible to achieve even in a markets of branded products. The brand requires a lot of investment, so the question of profitability is not of minor importance. The achievement of the goals of profitability requires two steps: firstl the perfect price positioning, and second, the price setting at the level of maximization of profit within the target segment, and third, the close coordination of price decisions with the promotion policy. It is worth noting that almost always the seller has the possibility of price discrimination, that is, the differentiation of prices across different consumer segments. But such a pricing policy requires special preparation, so leave this issue outside of the article.

Thus, the recommendations on effective pricing in branded markets can be reduced to the following rules. The price of the product shall be within price limits of the target consumer segment; otherwise, there will be dissonance between product and price positioning. The price is not the only tool of competition, so a company shall target its price to customers, not competitors. The price has a different effect on loyal and disloyal consumers, so try to divide it into two of these segments. The price should support changes in brand promotion, but price changes are always a loss, so appreciate the benefits of such a solution.

Based on these recommendations, it is possible to identify two types of pricing strategies that combine different pricing tools in a single set. The first strategy is to actively manage the price expectations of consumers. This strategy involves four steps:

Step 1. To establish clear price guidelines - to cultivate consumers with certain price levels, which will serve as referential ones. Refinancing prices may be prices for certain types of product (for example, parent complete sets of cars) or recommended retail price;

Step 2. To manage price trends - that is to set the price at the most important levels or to be able to reduce it depending on the market conditions;

Step 3. To form a favorable price comparison - to provide consumers with information about the price benefits of the product, taking into account the hidden costs or based on non-standard attributes if the products. For example, automobile dealers in the United States are actively using data on car maintanance costs and vehicle resale values over a period of time as a promotion message. And aviation companies display the price per kilometer of flight instead of the ticket price.

Step 4. Avoid unfavorable price comparisons by product differentiation - sometimes price difference relates only to different brands, not products. A good example is pricing on ultrabooks, which, for the same technical characteristics, are twice as expensive as a laptop. But target consumers do not compare these two products.

The second strategy involves the combination of value factors for consumers. This strategy passes three main steps:

Step 1. To increase consumer awareness of the full value of the product, such as IT and pharmaceutical companies, in any way, report the amount of their investments in new developments;

Step 2. To make product kits for the erosion of the cost of individual components - for example, comprehensive tourist products include accommodation, flight, meals, excursions, etc .; 
Step 3. To focus not on consumer spending, but on its benefits - to communicate to consumers the benefits that they get when they choose a particular product. For example, companies that manufacture household appliances, energy consumption of its products is stressed. That shifts conumers' attention on possible benefits, which justify the high price.

Conclusions and perspectives of further research. Thus, to achieve sustainable financial objectives shall consider mostly irrational pricing factors, among which the willingness or desire of consumers to pay a price for the product is the most prominent. Branded markets are determined by the predominance of irrational aspects of pricing. Therefore, the pricing strategy is aimed at the intensive use of communication tools. However, rational factors such as the volume of the target market segment, consumer value and competitive price also play an important role in shaping the financial success of pricing on markets of branded products.

Your company brand is the lifeblood of the business: It is a statement of your company's personality and a declaration of company values. With the right positioning strategy, branding creates an indelible impression that allows consumers to engage with a company on a more personal, emotional level. What's more, strong branding elevates awareness of both the company and the products or services it offers. To create this degree of awareness, you can using one of a number of positioning strategies to which you can anchor your brand.

\section{ЛІТЕРАТУРА}

1. Avlonitis, G. Pricing practices of service organizations. / Avlonitis, G., Indounas, K. A. // Journal of Service Marketing, - 2006. - 20(5), 346-356.

2. Besanko, D. A economia da estratégia (5th ed.)./ Dranove, D., Shanley, M., Schaefer, S.// - 2012. Porto Alegre: Bookman

3. Davcik, N. S. Impact of product differentiation, marketing investments and brand equity on pricing strategies: A brand level investigation./ Dranove, D., Shanley, M., Schaefer, S // European Journal of Marketing, - 2015. - 49(5/6), 760-781.

4. Field, A. Discovering statistics using IBM SPSS statistics (4th ed.). Thousand Oaks: Sage Publications, 2013.

5. Füreder, R. Value-based pricing in Austrian médium-sized companies./ Füreder R., Maier Y., Yaramova A. // Strategic Management, 2014. - 19(10), 13-19.

6. Hinterhuber, A. Innovation in pricing: Contemporary theories and best practices./ Hinterhuber A., Liozu. // 2013. - New York: Routledge.

7. Hinterhuber, A. Is innovation in pricing your nest source of competitive advantage?/ Hinterhuber A., Liozu. S. M. // Business Horizons, - 2014.- 57(3), 413-423.

8. Liozu, S. M. Pricing capabilities and firm performance: A socio-technical framework for the adoption of pricing as a transformational innovation. - 2013. - (Electronic Thesis or Dissertation). Retrieved from https://etd.ohiolink.edu/

9. Liozu S. Industrial pricing orientation: The organizational transformation to value-based pricing. /

Liozu S., Boland R., Hinterhuber A., Perelli S. // Paper presented at First International Conference on Engaged Management Scholarship, June 2, 2011. Available at SSRN: http://ssrn.com/abstract=1839838

10.Liozu S. M., Pricing orientation, pricing capabilities, and firm performance./ Liozu, S. M., Hinterhuber, A. // Management Decision, - 2013. - 51(3), 594-614.

11.Malhotra N. K. Marketing research: Applied approach (4th ed.). / Malhotra N. K., Birks D., Wills P. // New York: Pearson. - 2012.

12.Milan G. S. Relac,ão entre estratégias de prec,os e de custeio./ Milan G. S., De Toni D., Larentis F., Gava A. M. // Revista de Ciência da Administra,cão, -2013. - 15(36), 229-244.

13. Monroe K.B. Princing making profitable decisions (3rd ed.)./ Monroe K.B. // New York: McGrawHill/Irwin (international edition). - 2003.

14.Osborne J. W. Best practices in logistic regression./ Osborne J. W. // Thousand Oaks: Sage Publications. -2014.

15.Payne A. Developing superior value propositions:Astrategic marketing imperative./ Payne A.,

Frow P.// Journal of Service Management, - 2014. - 25(2), 213-227.

16.Simon H. Gerenciar para o lucro, não para a participa,cão de mercado./ Simon H., Bilstein F. R., Luby Frank. // Porto Alegre: Bookman. - 2008.

\section{REFERENCES}


1. Avlonitis G., \& Indounas K. A. (2006). Pricing practices of service organizations. Journal of Service Marketing, 20(5), 346-356. [in English]

2. Besanko D., Dranove, D., Shanley M., \& Schaefer S. (2012). A economia da estratégia (5th ed.). Porto Alegre: Bookman [in Catalan]

3. Davcik N. S., \& Sharma P. (2015). Impact of product differentiation, marketing investments and brand equity on pricing strategies: A brand level investigation. European Journal of Marketing, 49(5/6), 760-781. [in English]

4. Field A. (2013). Discovering statistics using IBM SPSS statistics (4th ed.). Thousand Oaks: Sage Publications. [in English]

5. Füreder R., Maier Y.\&Yaramova A. (2014). Value-based pricing in Austrian médium-sized companies. Strategic Management, 19(10), 13-19. [in English]

6. Hinterhuber A., \& Liozu. (2013). Innovation in pricing: Contemporary theories and best practices. New York: Routledge. [in English]

7. Hinterhuber A., \& Liozu. (2014). Is innovation in pricing your nest source of competitive advantage? Business Horizons, 57(3), 413-423. [in English]

8. Liozu S. M. (2013). Pricing capabilities and firm performance: A socio-technical framework for the adoption of pricing as a transformational innovation. (Electronic Thesis or Dissertation). Retrieved from https://etd.ohiolink.edu/[in English]

9. Liozu S., Boland R., Hinterhuber A., \& Perelli S. (2011). Industrial pricing orientation: The organizational transformation to value-based pricing. Paper presented at First International Conference on Engaged Management Scholarship, June 2, 2011. Available at SSRN: http://ssrn.com/abstract=1839838 [in English]

10.Liozu S. M., \& Hinterhuber A. (2013). Pricing orientation, pricing capabilities, and firm performance. Management Decision, 51(3), 594-614. [in English]

11.Malhotra N. K., Birks D., \& Wills P. (2012). Marketing research: Applied approach (4th ed.). New York: Pearson. [in English]

12.Milan G. S., De Toni D., Larentis F., \& Gava A. M. (2013). Relac,ão entre estratégias de prec,os e de custeio. Revista de Ciência da Administra, cão, 15(36), 229-244. [in Catalan]

13. Monroe K.B. (2003). Princing making profitable decisions (3rd ed.). New York: McGraw-Hill/Irwin (international edition). [in English]

14.Osborne J. W. (2014). Best practices in logistic regression. Thousand Oaks: Sage Publications. [in English]

15.Payne A.,\&Frow P.(2014).Developing superior value propositions:Astrategic marketing imperative. Journal of Service Management, 25(2), 213-227. [in English]

16.Simon H., Bilstein F. R., \& Luby Frank. (2008). Gerenciar para o lucro, não para a participa,cão de mercado. Porto Alegre: Bookman. [in Catalan] 